\title{
Belowground functioning of agroforestry systems: recent advances and perspectives
}

\author{
Rémi Cardinael $\cdot$ Zhun Mao • Claire Chenu • \\ Philippe Hinsinger
}

Received: 13 May 2020 / Accepted: 6 July 2020 / Published online: 10 July 2020

(C) Springer Nature Switzerland AG 2020

\section{Introduction}

Growing crops or pastures in intimate combination with trees is an ancient practice that farmers have been using throughout the world. Globally, it is estimated that agroforestry systems cover about 1 billion hectare of land (Zomer et al. 2014, 2016). Agroforestry systems are often seen by farmers and practitioners as a way to diversify production, income and services (Abdulai et al. 2018). These systems are still very common in developing

Responsible Editor: Hans Lambers

R. Cardinael

CIRAD, UPR AIDA, Harare, Zimbabwe

R. Cardinael

AIDA, University of Montpellier, CIRAD, Montpellier, France

R. Cardinael $(\bowtie)$

Crop Science Department, University of Zimbabwe, Mt. Pleasant, Box MP167, Harare, Zimbabwe

e-mail: remi.cardinael@ cirad.fr

\section{Z. Mao}

AMAP, University of Montpellier, CIRAD, CNRS, INRAE, IRD, Montpellier, France

C. Chenu

UMR Ecosys, INRAE, Université Paris Saclay,

AgroParisTechThiverval-Grignon, France

P. Hinsinger

Eco\&Sols, University of Montpellier, CIRAD, INRAE, Institut

Agro, IRD, Montpellier, France countries. In developed countries where the intensification and specialization of agriculture have resulted in a massive loss of tree cover (Eichhorn et al. 2006) and in negative impacts on the environment (Tilman et al. 2001), agroforestry systems are currently being reconsidered and spreading (den Herder et al. 2017). Agroforestry systems include a diversity of practices ranging from complex associations found in homegardens, multistrata systems or agroforests, to simpler systems such as alley crops, riparian plantings, shelterbelts, windbreaks or hedgerows (Nair 1985). The association between trees and crops or pastures can be simultaneous (spatial interaction) or sequential (temporal interaction) (Somarriba 1992; Torquebiau 2000).

The management of the aboveground part of agroforestry systems to deal with the competition for light has received considerable interest (e.g. Charbonnier et al. 2013; Bouttier et al. 2014). However, trees also modify soil properties through numerous processes (Rhoades 1997), and tree-soil-crop interactions have been a research topic for decades (Szott et al. 1991; Lehmann et al. 1998; Schroth 1998; Ilstedt et al. 2016; van Noordwijk et al. 2019). Tree and crop root systems play a crucial role in these interactions (Schroth 1995; van Noordwijk et al. 1996; Smith et al. 1999; Bayala et al. 2015) and are involved in most of belowground processes (Bardgett et al. 2014), which determine soil functions and, ultimately, a large set of ecosystem services. A better understanding of these processes at the interface between soil science and agroforestry, such as soil organic carbon sequestration or water infiltration, could thus help reaching some the United Nations 
Sustainable Development Goals (Keesstra et al. 2016; van Noordwijk et al. 2018).

The aim of this special issue "Agroforestry: a belowground perspective" was to bring together new contributions and developments about belowground processes and tree-soil-crop interactions in agroforestry systems. We received a total of 40 manuscripts of which 13 have been accepted for publication. Among these papers, nine are original research papers and four are invited reviews, including a Marschner review. Original research papers include a large diversity of agroforestry systems, such as fallows, parklands, shaded perennialcrop systems and silvoarable systems from six different countries and seven different climatic zones (Table 1; Fig. 1). The different papers cover very different aspects of belowground functioning and numerous processes are studied (Table 2). The manuscripts were grouped into three major topics: (1) water cycling in soils under agroforestry systems; (2) closing the loop: soil nutrient cycling in agroforestry systems; (3) soil organic carbon cycling in agroforestry systems. For each of these sections we provide an overview of our current knowledge, highlight the contributions of this special issue, and pinpoint key remaining challenges for future work.

\section{Water cycling in soils under agroforestry systems}

In the context of climate change that renders global terrestrial water resources more vulnerable (Vörösmarty et al. 2000; Porporato et al. 2004; Falkenmark 2013), the impact of agroforestry on water cycling processes has drawn increasing attention. Compared to intensive monoculture, agroforestry systems are expected to better promote water cycling processes (e.g. water infiltration and retention, reduced run-off) and hydrological ecosystem services due to their higher spatial complexity and biodiversity (Rowe et al. 1998; Liu et al. 2016; Pavlidis and Tsihrintzis 2018). Competition for water between trees and annual crops has often been shown (Jose et al. 2000b), but agroforestry systems also have the potential to improve the acquisition of water through complementary root distributions, trees having deeper root systems than annual crops (Jackson et al. 1996; Cardinael et al. 2015b; Germon et al. 2016), and further to promote water sharing mechanisms such as a redistribution of water in the soil profile through a process called hydraulic lift, or through shared mycorrhizal networks. Yet, to which extent such effects are significant and can be generalized remains unknown. To

Table 1 Summary details of articles published within the special issue

\begin{tabular}{|c|c|c|c|c|c|}
\hline Study & Paper type & Agroforestry system & Association & Study site & $\begin{array}{l}\text { Köppen } \\
\text { climate }\end{array}$ \\
\hline $\begin{array}{l}\text { Battie-Laclau et } \\
\text { al. (2020) }\end{array}$ & Original research & Silvoarable system & Juglans nigra / cereals & France & $\mathrm{Cfb}$ \\
\hline $\begin{array}{l}\text { Bayala and Prieto } \\
\text { (2020) }\end{array}$ & Review & Diverse & Diverse & Worldwide & Diverse \\
\hline Borden et al. (2020) & Original research & $\begin{array}{l}\text { Shaded perennial-crop } \\
\text { system }\end{array}$ & Shade trees / Theobroma cacao & Ghana & Aw \\
\hline Clivot et al. (2020) & Original research & Silvoarable system & $\begin{array}{l}\text { Populus deltoides } \times \text { P. nigra / alfafa } \\
\text { Alnus glutinosa / wheat / } \\
\quad \text { triticale / ryegrass }\end{array}$ & France & $\mathrm{Cfb}$ \\
\hline Huo et al. (2020) & Original research & Silvoarable system & Ziziphus jujube / canola / daylily & China & Dwa \\
\hline Isaac and Borden (2020) & Marschner Review & Diverse & Diverse & Worldwide & Diverse \\
\hline Ling et al. (2020) & Original research & Silvoarable system & Ziziphus jujube / canola / daylily & China & Dwa \\
\hline Marsden et al. (2020) & Review & Diverse & Diverse & Worldwide & Diverse \\
\hline Rigal et al. (2020) & Original research & $\begin{array}{l}\text { Shaded perennial-crop } \\
\text { system }\end{array}$ & Shade trees / Coffea arabica & China & Cwa \\
\hline Sida et al. (2020) & Original research & Parkland & $\begin{array}{l}\text { Faidherbia albida / Acacia } \\
\quad \text { tortilis / Grevillea } \\
\quad \text { robusta } \times \text { cereals }\end{array}$ & $\begin{array}{l}\text { Ethiopia } \\
\text { Rwanda }\end{array}$ & BSh \\
\hline Terefe and Kim (2020) & Original research & Fallows & Multiple tree species $\times$ cereals & Ethiopia & $\mathrm{Cwb}$ \\
\hline Wartenberg et al. (2020) & Original research & $\begin{array}{l}\text { Shaded perennial-crop } \\
\text { system }\end{array}$ & Theobroma cacao $\times$ shade trees & $\begin{array}{l}\text { Sulawesi, } \\
\text { Indonesia }\end{array}$ & Af \\
\hline Zhu et al. (2020) & Review & Diverse & Diverse & Worldwide & Diverse \\
\hline
\end{tabular}




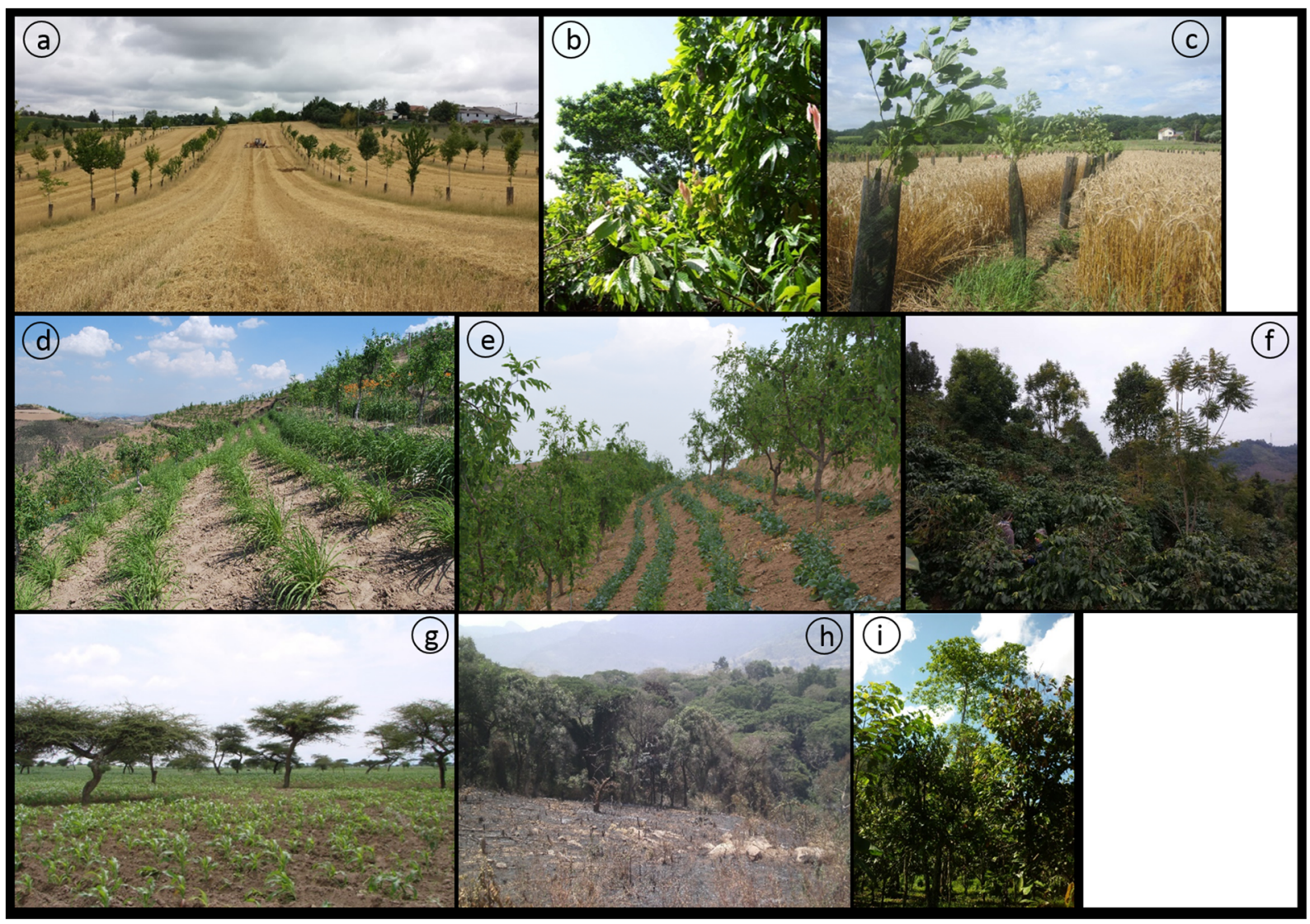

Fig. 1 Pictures illustrating the diversity of the study sites investigated in the original research papers published within this special issue. a Walnut trees and other high value hardwood tree species (Fraxinus excelsior L., Sorbus torminalis L., and S. domestica L., Prunus avium L., Acer pseudoplatanus L.) associated with soft wheat, Noilhan, France (Battie-Laclau et al. 2020) (Patricia Battie-Laclau; b Cocoa trees with Terminalia ivorensis, Ashanti Region, Ghana (Borden et al. 2020) (CKira Borden; c Alder trees and triticale, La Bouzule, France (Clivot et al. 2020) (ONicolas Marron; d Jujube trees with Brassica napus, The Loess Plateau of China (Huo et al. 2020) CGaopeng Huo; e Jujube trees with

address these crucial points, Bayala and Prieto (2020) presented an original review on the acquisition, sharing and redistribution of water by roots in agroforestry systems. They found that root competition between crops and trees is a common phenomenon, and that farmers can use several techniques to alleviate it to some extent, such as crown reduction, tree pruning and a proper selection of trees and crops. They also highlighted that the hydraulic lift could constitute a very relevant mechanism to ensure productivity of agroforestry systems in regions with erratic rainfalls. Finally, they suggested several research perspectives, such as the clarifying the role of mycorrhizal networks daylily, The Loess Plateau of China (Ling et al. 2020) @Qiang Ling; f Arabica coffee trees with various shade tree species (including Jacaranda mimosifolia, Cinnamomum camphora and Bishofia javanica), Yunnan Province, China (Rigal et al. 2020) (C)Clément Rigal; g Acacia tortilis with maize, Meki, Ethiopia (Sida et al. 2020) CFrédéric Baudron; h Shifting cultivation, Gudeya Billa District, western Ethiopia (Terefe and Kim 2020) CDong-Gill Kim; i Cocoa trees with Anthoccephalus cadamba, Wonuahoa, Southeast Sulawesi, Indonesia (Wartenberg et al. 2020) (CAriani Wartenberg

in the hydraulic lift, as well as quantifying the volume of water transferred to neighboring plants through hydraulic lift. In addition to this review paper, Huo et al. (2020) carried out a case study in a semiarid agroforestry system in the Loess Plateau in the north of China to characterize water uptake strategies and hydraulic redistribution between trees and crops, using an in situ approach based on stable isotopes $\left({ }^{2} \mathrm{H}\right.$ and $\left.{ }^{18} \mathrm{O}\right)$. Inter- and intra-annual dynamics of soil water content (SWC) were monitored in two systems: an agroforestry system with jujube (Ziziphus jujuba Mill.) trees intercropped with canola (Brassica napus L.) or daylily (Hemerocallis fulva L.), and a pure jujube tree 


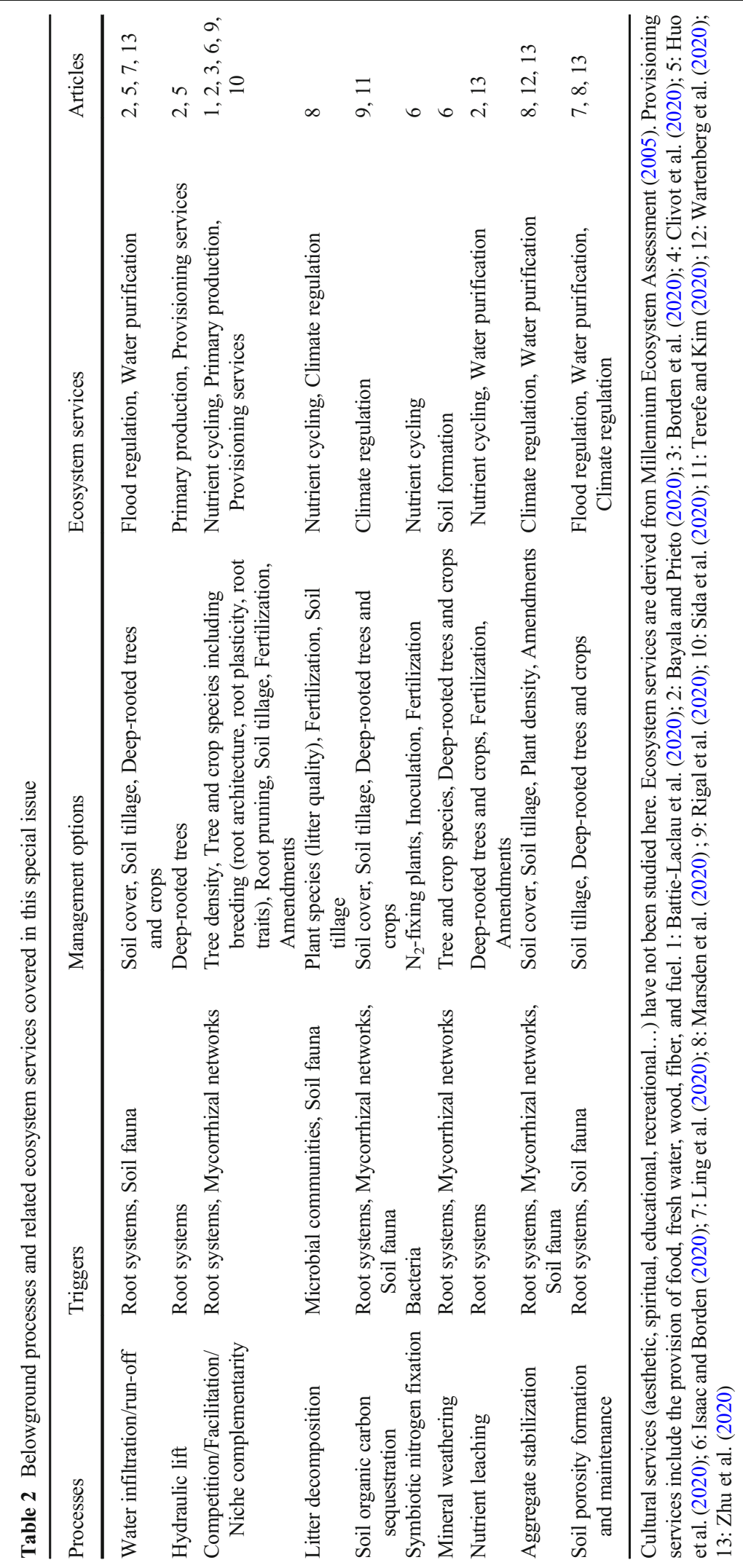


plantation as a control plot. This study showed the highly plastic behavior of the agroforestry system in water uptake strategy depending on soil depth and season at the early stage of land-use change from plantation to agroforestry. Within the soil layers where crop roots were largely present (0-1.2 $\mathrm{m}$ depth), jujube trees in the agroforestry system were able to obtain more shallow water $(0-20 \mathrm{~cm}$ or $20-60 \mathrm{~cm})$ during wet periods, but more deep water $(60-120 \mathrm{~cm})$ during dry periods. It shall be noted that this study includes some precious water data from very deep soil layers (down to $4 \mathrm{~m}$ ). The authors demonstrated that, in the driest season, trees in agroforestry systems could take up very deep soil water (down to $4 \mathrm{~m}$ ). According to the authors, while this is good for tree metabolic maintenance, it may also induce a strong desiccation of very deep soil layers as the ground water level was too deep ( $>50 \mathrm{~m}$ ) to compensate for such a water stress. However, this negative effect could be partly offset by increased soil water infiltration (Ilstedt et al. 2016; Liu et al. 2016).

Concerning water movement on soil surfaces and shallow soil layers, stratified tree canopies over crops in agroforestry systems have been found to effectively reduce water loss through runoff and soil loss due to erosion (Villatoro-Sánchez et al. 2015; Liu et al. 2016). Litterfalls from trees can further increase soil surface rugosity and soil aggregate stability, while tree roots can increase soil porosity, thus resulting in increased water infiltration and ultimately limiting water erosion (Liu et al. 2016). Yet, to which extent such effects can be generalized over a global scale and across different types of agroforestry systems remains unknown. To fill such a gap, Zhu et al. (2020) performed a systematic review to quantitatively assess the impact of agroforestry systems on erosion control and associated environmental issues, such as soil nutrient losses and pollutant dispersion, for four types of agroforestry systems in temperate and tropical regions. While this review successfully confirmed the general positive effect of agroforestry systems, it also showed large discrepancies of the performance of agroforestry systems amongst the various case studies. This suggests the necessity of optimizing soil and vegetation management depending on the context of the agroforestry systems. Zhu et al. (2020) mainly focused on water processes at the surface of soils, or at sub-surface, but also highlighted a lack of research on the role of belowground soil-root-biota interaction in the regulation of water processes in agroforestry systems, especially for deep soil layers. Water processes at depth are largely mediated by those occurring in shallow and deep soil horizons, which can be susceptible to the distribution patterns of tree and crop roots, as well as their associated soil biota (e.g. macrofauna, mycorrhizal fungi etc.). Roots and soil biota can influence belowground water processes either by direct hydraulic redistribution in soil due to their water absorption and sharing strategies or by modifying soil hydrological and hydraulic properties, e.g., water storage capacity, infiltration rate and hydraulic conductivity. In addition to this global synthesis, Ling et al. (2020) proposed an original case study in a similar context as for the study of Huo et al. (2020), but on a different plot. The authors characterized soil water content, root distribution and soil physical properties related to soil water cycling processes in an agroforestry system with jujube (Ziziphus jujuba Mill.) trees intercropped with canola (Brassica napus L.) or daylily (Hemerocallis fulva L.), and in a pure jujube tree plantation as a control plot. They found that, compared to a monoculture of jujube tree plantation, the agroforestry system could decrease soil bulk density and increase field capacity, saturated hydraulic conductivity and soil porosity, especially in inter-rows, thus having a generally positive effect on soil water cycling and vegetation performance. In addition, the study showed a lower soil water content in the agroforestry system inter-rows, suggesting a competition for water between trees and intercropped species.

\section{Closing the loop: soil nutrient cycling in agroforestry system}

Research on nutrient cycling in agroforestry systems has been prolific for decades (Nair et al. 1999). The following questions have been largely addressed: the contribution of agroforestry trees to nutrient requirements of intercropped plants and the timing of nutrient transfer from the decomposition of the pruning residues to intercrops (Palm 1995; Zingore et al. 2003; Tully and Lawrence 2012), the competition for nitrogen (Jose et al. 2000a; Zamora et al. 2009), the use of nitrogenfixing trees and their effect on crop production (Akinnifesi et al. 2010), the uplift of deep subsoil nutrients by trees (Vanlauwe et al. 2005) and the role of tree roots as a safety-net to reduce nutrient leaching (Rowe et al. 1998; Bergeron et al. 2011; Tully et al. 2012). Functional trait-based approach has been evidenced to 
be efficient explaining plant strategies related to nutrient use (Garnier and Navas 2012). While such an approach is widely used in plant ecology, it is still poorly explored in the context of agroforestry systems where tree and crops can show intra- and interspecific facilitation or competition interactions. The Marschner review of Isaac and Borden (2020) is therefore very timely. The authors reviewed the processes underpinning nutrient acquisition in agroforestry systems, including root distribution and plasticity, biological nitrogen fixation and deep soil nutrient uplift. They also pointed that understanding these mechanisms requires consideration of the multiple scales at which trees and crops interact with each other and acquire nutrients from soil. They further explained that interspecific root overlap is often associated with nutrient competition, but several studies also evidenced facilitation for nutrient acquisition through enhanced chemically and microbially meditated processes. They finally suggested that root functional trait-based approach is promising in its ability to capture the multi-scalar nature of nutrient acquisition processes in agroforestry systems. In addition to this review paper, Borden et al. (2020) focused on a cocoa (Theobroma cacao L.) agroforestry system in Ghana including two shade tree species (Terminalia ivorensis Chev., Entandrophragma angolense (Welw.) C.DC.). They mapped root distribution, root functional traits and soil nutrients down to $60-\mathrm{cm}$ depth. They found that the species of shade tree induced root plasticity in T. cacao. Cocoa root morphological traits indeed shifted towards a nutrient acquisition strategy, exhibiting higher specific root length and lower fine root tissue density, when next to a shade tree. They also showed that root traits plasticity depended on the soil nutrient $\left(\mathrm{Ca}^{2+}\right.$, $\mathrm{NH}_{4}{ }^{+}, \mathrm{NO}_{3}{ }^{-}$).

Through their symbiotic relationship with roots, the crucial role of mycorrhizal fungi in nutrient acquisition has been generally recognized (Barea et al. 2005). However, the effect of trees on the abundance, diversity and activity of mycorrhizal communities is still poorly known (Bainard et al. 2011, 2012). The tree-crop mixed cultivation in agroforestry systems provides a valuable opportunity to investigate this. Battie-Laclau et al. (2020) studied the respective role of trees and herbaceous vegetation beneath trees in maintaining arbuscular mycorrhizal communities in temperate alley cropping agroforestry systems. They showed that roots of trees and associated herbaceous vegetation were extending several meters within the cropped alley in the topsoil, challenging the common view of a stratification and niche separation of tree and crop roots. Such intermingled root systems are an important feature for potential plant-plant interactions in agroforestry systems, e.g. facilitation processes through sharing common mycorrhizal communities and networks. Surprisingly, they showed that the herbaceous vegetation beneath the trees was better at maintaining an active arbuscular mycorrhizal network than associated tree roots. They therefore suggested that a proper selection of plant species sown under the trees could benefit the development of the annual intercrop. In addition, their study pointed the major contribution of the herbaceous vegetation beneath the trees to plant diversity and to their associated above- and belowground biodiversity.

Studies on nutrient provision in agroforestry systems have mostly focused on tree litter decomposition and release of nutrients from pruning residues, in terms of amounts and use efficiency (Palm 1995; Montagnini et al. 1999; Gnankambary et al. 2008) as well as on biological $\mathrm{N}_{2}$-fixation (Chikowo et al. 2004). However, studies on the nutrient use efficiency of mineral fertilization in agroforestry systems remain scanty (Cannavo et al. 2013). Sida et al. (2020) designed an original trial to disentangle tree-crop-fertilizer interactions in several agroforestry systems in Ethiopia and Rwanda. They found that in parkland with the nitrogen-fixing tree species Faidherbia albida (Delile) A. Chev., the addition of nitrogen only had not effect on wheat yields under the canopy compared to nitrogen addition in open field plots, while the application of phosphorus only doubled the wheat grain yields. Moreover, the phosphorus use efficiency was doubled under the canopy of Faidherbia albida. Phosphorus was therefore more limiting than nitrogen for wheat production under the canopy of Faidherbia albida, and nitrogen fertilization could be saved under tree canopies. The phenology of Faidherbia albida is unique as it sheds its leaves during the rainy season, and cattle usually graze under its canopy during the dry season, potentially bringing some nitrogen, but also phosphorus and potassium through their dejections. On the opposite, the yield and nutrient use efficiency were reduced for maize grown under another nitrogenfixing tree species Acacia tortilis (Forssk.) Hayne and Grevillea robusta A.Cunn. ex R.Br. Processes of facilitation and competition are therefore site-specific and fertilizer recommendations should account for local conditions (soil type and fertility level) and the type of agroforestry systems (tree and crop species). 


\section{Soil organic carbon cycling in agroforestry systems}

Early research on agroforestry systems has focused on the effect on soil organic matter and soil fertility (Young 1989; Onim et al. 1990; Chander et al. 1998). More recently, research on soil fertility in agroforestry systems was extended to the concepts of soil health and soil quality (Barrios et al. 2012; Muchane et al. 2020). In the last two decades, the burning issue of global warming induced a new research in agroforestry systems, with a huge increase in the number of articles dealing with climate change mitigation via carbon sequestration in soils (van Noordwijk et al. 2019). Despite the important diversity of agroforestry systems, recent reviews and meta-analyses suggest that the conversion of arable land to agroforestry systems leads to increased soil organic carbon (SOC) stocks (Lorenz and Lal 2014; Kim et al. 2016; Cardinael et al. 2018b; Feliciano et al. 2018; Shi et al. 2018; Corbeels et al. 2019), and these systems are now better taken into account in the 2019 Refinement to the 2006 IPCC Guidelines for National Greenhouse Gas Inventories (Cardinael et al. 2018b; Ogle et al. 2019), which is a critical but insufficient step to gain access to finance and other support (Rosenstock et al. 2019). SOC storage at the plot scale is controlled by a balance between organic carbon inputs and losses. In agroforestry systems, higher organic carbon inputs to the soil are often observed compared to treeless croplands (Cardinael et al. 2018a), as a result of tree litterfall (Sileshi and Mafongoya 2007; Negash and Starr 2013) and pruning residues (Zingore et al. 2003; Nyamadzawo et al. 2012), but also tree root inputs (Sierra and Nygren 2005; Germon et al. 2016). Increased organic inputs under trees are also due to tree canopy throughfall inputs, nutrients and to soil particles transported by the wind and captured by tree canopy (Bielders et al. 2002), accumulation of windborne soil around trunks, as well as fecal inputs from perching bird or grazing animals (Rhoades 1997). Increased biomass production at the plot scale (Graves et al. 2010) and organic inputs might explain the enhanced SOC sequestration in agroforestry systems. Besides, other soil and soil biota related processes favored by agroforestry systems can promote higher SOC sequestration, such as enhanced aggregate stability (Udawatta et al. 2008) promoting SOC stability and reduced erosion due to increased water infiltration and reduced runoff (Anderson et al. 2009).

Several authors found an increase abundance, biomass and diversity of earthworms in agroforestry systems (Price and Gordon 1999; Cardinael et al. 2019b). Soil fauna is largely involved in litter and SOC decomposition (Lavelle et al. 2006) and its effect on SOC stabilization is still debated (Frouz et al. 2015; Lubbers et al. 2017). Agricultural practices largely impact soil biota (Ponge et al. 2013) but very little is known about agroforestry systems. To fill this knowledge gap, Marsden et al. (2020) performed a systematic review on the effect of agroforestry systems on soil macro, meso and microfauna and their functions. They found that most studies have so far focused on soil macrofauna community (abundance, diversity and biomass) in agroforestry compared to a reference plot. They showed that the effects on fauna abundance and diversity are mainly positive when agroforestry is compared to cropland, and neutral or negative when compared to forests. However, soil fauna functions in agroforestry systems were only studied in 17 out of the 67 retrieved papers. Interestingly, the main soil function addressed was soil structure maintenance, while very few studies investigated the role of soil fauna on carbon and nutrient cycling in agroforestry systems.

Several years, often a decade, are necessary to detect a change in SOC stocks (Smith 2004). However, early changes in SOC dynamics can be tracked using early indicators such as some soil fractions or soil enzyme activities. Rigal et al. (2020) and Clivot et al. (2020) both studied such early changes, four years after tree planting in very different contexts. In Rigal et al. (2020) studied the effect of three shade tree species (Cinnamomum camphora (L.) J. Presl, Bishofia javanica Blume, Jacaranda mimosifolia D.Don) on soil quality in a coffee (Coffea arabica L.) agroforestry system. More specifically, they characterized soil enzyme activities, soil microbial communities, including arbuscular mycorrhiza fungi (AMF) and non-AMF fungi, nematode communities, as well as soil chemical properties. They observed a significant increase in the abundance of bacterial and fungal communities in shaded areas compared to open areas, especially during the dry season, and a significant build-up of soil organic matter under shaded coffee. As the yields of shaded coffee were maintained, except under C. camphora, they concluded that carefully selected shade trees could rapidly contribute to restoring soil quality, while maintaining high coffee yields. In France, Clivot et al. (2020) studied the effect of two alley cropping agroforestry systems, poplar (Populus deltoides $\times$ P. nigra)-alfalfa (Medicago sativa L.) and alder (Alnus glutinosa L.)- 
ryegrass (Lolium perenne L.) on several soil properties and microbial and enzymatic activity, compared to treeless control plots. No significant differences in SOC contents nor in labile soil organic matter fractions were found in the topsoil $(0-15 \mathrm{~cm})$. Microbial enzyme activity varied greatly across years, but no general trend was found. However, near-infrared and mid-infrared spectroscopy showed a differentiation in soil organic matter quality between the poplar-alfalfa agroforestry system compared to the alfalfa treeless plots. In contrast, Guillot et al. (2019) reported in an older alley cropping agroforestry system with hybrid walnut trees that there was an increased microbial biomass and activity in the alley, beyond the tree row. In such agroforestry systems, as also pointed by Battie-Laclau et al. (2020), such effects on soil microbial communities are possibly impacted by the herbaceous vegetation beneath trees, not just by the trees.

Farmers implement various agroforestry systems to restore soil fertility, such as planting nitrogen-fixing shade trees, or shifting cultivation. Wartenberg et al. (2020) and Terefe and Kim (2020) studied changes in soil fertility and SOC contents and stocks in these two systems, respectively. More specifically, Wartenberg et al. (2020) investigated the interactions between 11 commonly intercropped shade trees and cocoa trees in cocoa (Theobroma cacao L.) agroforests in Sulawesi, and their impact on cocoa productivity and on some soil properties, such as aggregate stability. Mean weight diameter of stable aggregates are key indicators of the fate of macro- and micro-aggregates in soils, both involved in the stabilization of SOC (Oades 1984; Six et al. 2004). While many studies have focused on soil tillage (Six et al. 2000), little is still known about the effect of agroforestry systems on soil aggregates (Udawatta et al. 2008). The authors found that SOC, soil nitrogen and aggregate mean weight diameter were increased under shade tree canopies compared to open areas. Cocoa tree growth was reduced but with no adverse effects on cocoa yields. Interestingly and similarly to Rigal et al. (2020), the authors suggested that shade trees do not always induce a direct trade-off between yield and soil fertility. In Ethiopia, Terefe and Kim (2020) studied shifting cultivation systems, an example of sequential agroforestry, with different fallowing durations compared to adjacent monocropping fields and a natural forest. The authors found that long-term shifting cultivation did not affect soil $\mathrm{pH}$, soil organic carbon (SOC) and soil total nitrogen stocks compared to the forest. However, the conversion of shifting agriculture to conventional monocropping resulted in a huge loss of SOC stocks (about $-50 \%$ over 10 years). Shifting cultivation is therefore a relevant practice to maintain high SOC stocks.

\section{Conclusion and perspectives}

To better understand the belowground functioning of agroforestry systems, a considerable effort has been made over the recent years to explore the various and numerous processes in diverse types of agroforestry systems. This special issue is a perfect illustration of such an effort, gathering studies dealing with different topics and approaches related to a broad range of disciplines such as soil ecology and biology, hydrology, biochemistry, ecophysiology, ecology and agronomy. However, a comprehensive understanding of the belowground functioning of these systems is still lacking, because numerous and complex site-specific interactions and trade-offs are at play. We summarize here what we think should be further explored in the coming decade. Future works should:

- Document temporal dynamics. More precisely, future studies should study the processes on the long-term, and better document temporal effects (seasonal, year-to-year, short- vs. long-term effects). For instance, significant changes in SOC stocks can only be observed on the long-term while short-term transitional effects might be misleading. Maintaining long-term trials is critical in that respect.

- Investigate spatial dynamics. Future studies should better document lateral spatial heterogeneities generated in such systems (Battie-Laclau et al. 2020; Marsden et al. 2020), depending on the types of agroforestry systems and spatial arrangement of trees, and how these affect soil functions and related ecosystem services (Cardinael et al. 2017, 2019b; Roupsard et al. 2020). Beyond the role of trees, that of the herbaceous cover under the trees shall also be better accounted for (Cardinael et al. 2017, 2018a; Battie-Laclau et al. 2020), whenever present, or the contribution of grazing animals, when relevant, as they are likely to be additional sources of heterogeneity. 
- Dig deeper. Several papers of this special issue were innovative in also focusing on deep soil layers (Battie-Laclau et al. 2020; Ling et al. 2020; Terefe and Kim 2020; Huo et al. 2020). Deep-rooting of trees in agroforestry systems is likely to impact the whole soil profile (Mulia and Dupraz 2006; Cardinael et al. 2015b) and better understanding of soil processes at depth is critical for water and nutrient cycling (Bayala and Prieto 2020; Isaac and Borden 2020), as well as for carbon sequestration (Cardinael et al. 2015a, 2018a, 2019a) as also summarized in recent reviews on the role of deep roots (Maeght et al. 2013; Thorup-Kristensen et al. 2020; Germon et al. 2020).

- Be integrative. Develop an integrative approach, linking above- and belowground processes, and also coupling the cycling of different elements, such as water, nutrients and carbon. Modelling of agroforestry systems should be particularly developed towards this aim (Luedeling et al. 2016; Dupraz et al. 2019). For instance, the complete radiative forcing of agroforestry systems should be quantified including a balance of greenhouse gases and if possible also changes in biophysical effects such as albedo. Only quantifying the carbon balance of agroforestry systems might lead to a biased understanding in their role towards climate change mitigation. Only a few studies have focused on nitrous oxide $\left(\mathrm{N}_{2} \mathrm{O}\right)$ emissions in agroforestry (Kim et al. 2016) and on the role of nitrogen-fixing trees in such emissions (Rosenstock et al. 2014). Beyond the potential contribution of agroforestry systems to climate change mitigation, how such systems adapt to climate change compared to conventional cropping systems shall deserve further consideration.

- Embrace diversity. Globally, agroforestry systems are very diverse, and some are poorly studied. More data should be for instance collected in temperate agroforestry systems, as works on tropical agroforestry systems are over-represented by now. Only two studies in this special issue presented new data on temperate agroforestry systems (Battie-Laclau et al. 2020; Clivot et al. 2020) despite the growing development of such systems in temperate regions of the world.

- Highlight the multifunctionality. The multifunctional features of agroforestry systems should be better taken into account in management practices. This demands future studies to understand and characterize a larger and more transdisciplinary pool of ecosystem services in the assessment of agroforestry systems, not only biophysical indicators of soil ecosystem functions and services, but also when possible, social and economic indicators. Simultaneously, future studies should analyze synergies and trade-offs among expected ecosystem functions and services. Rigal et al. (2020) and Wartenberg et al. (2020) both reported an absence of trade-off between yield and soil fertility, but this might not be the case everywhere. Synergies and trade-offs among ecosystem services could then be optimized to achieve multifunctional agroforestry systems (Andreotti et al. 2018).

\section{References}

Abdulai I, Jassogne L, Graefe S et al (2018) Characterization of cocoa production, income diversification and shade tree management along a climate gradient in Ghana. PLoS One 13:117. https://doi.org/10.1371/journal.pone.0195777

Akinnifesi FK, Ajayi OC, Sileshi G et al (2010) Fertiliser trees for sustainable food security in the maize-based production systems of East and Southern Africa. A review. Agron Sustain Dev 30:615-629. https://doi.org/10.1051/agro/2009058

Anderson SH, Udawatta RP, Seobi T, Garrett HE (2009) Soil water content and infiltration in agroforestry buffer strips. Agrofor Syst 75:5-16. https://doi.org/10.1007/s10457-0089128-3

Andreotti F, Mao Z, Jagoret P et al (2018) Exploring management strategies to enhance the provision of ecosystem services in complex smallholder agroforestry systems. Ecol Indic 94: 257-265. https://doi.org/10.1016/j.ecolind.2018.06.048

Bainard LD, Koch AM, Gordon AM et al (2011) Influence of trees on the spatial structure of arbuscular mycorrhizal communities in a temperate tree-based intercropping system. Agric Ecosyst Environ 144:13-20. https://doi.org/10.1016/j. agee.2011.07.014

Bainard LD, Koch AM, Gordon AM, Klironomos JN (2012) Temporal and compositional differences of arbuscular mycorrhizal fungal communities in conventional monocropping and tree-based intercropping systems. Soil Biol Biochem 45: 172-180. https://doi.org/10.1016/j.soilbio.2011.10.008

Bardgett RD, Mommer L, De Vries FT (2014) Going underground: Root traits as drivers of ecosystem processes. Trends Ecol Evol 29:692-699. https://doi.org/10.1016/j. tree.2014.10.006

Barea J-M, Pozo MJ, Azcon R, Azcon-Aguilar C (2005) Microbial co-operation in the rhizosphere. J Exp Bot 56:1761-1778. https://doi.org/10.1093/jxb/eri197

Barrios E, Sileshi GW, Shepherd K, Sinclair F (2012) Agroforestry and Soil Health: Linking Trees, Soil Biota, and Ecosystem Services. In: Wall DH, Bardgett RD, 
Behan-Pelletier V, et al. (eds) Soil Ecology and Ecosystem Services. Oxford University Press, pp 315-330

Battie-Laclau P, Taschen E, Plassard C et al (2020) Role of trees and herbaceous vegetation beneath trees in maintaining arbuscular mycorrhizal communities in temperate alley cropping systems. Plant Soil. https://doi.org/10.1007 /s11104-019-04181-z

Bayala J, Prieto I (2020) Water acquisition, sharing and redistribution by roots: applications to agroforestry systems. Plant Soil. https://doi.org/10.1007/s11104-019-04173-z

Bayala J, Sanou J, Teklehaimanot Z et al (2015) Advances in knowledge of processes in soil-tree-crop interactions in parkland systems in the West African Sahel: A review. Agric Ecosyst Environ 205:25-35. https://doi.org/10.1016/j. agee.2015.02.018

Bergeron M, Lacombe S, Bradley RL et al (2011) Reduced soil nutrient leaching following the establishment of tree-based intercropping systems in eastern Canada. Agrofor Syst 83: 321-330. https://doi.org/10.1007/s10457-011-9402-7

Bielders CL, Rajot JL, Amadou M (2002) Transport of soil and nutrients by wind in bush fallow land and traditionally managed cultivated fields in the Sahel. Geoderma 109:19-39. https://doi.org/10.1016/S0016-7061(02)00138-6

Borden KA, Thomas SC, Isaac ME (2020) Variation in fine root traits reveals nutrient-specific acquisition strategies in agroforestry systems. Plant Soil. https://doi.org/10.1007/s11104019-04003-2

Bouttier L, Paquette A, Messier C et al (2014) Vertical root separation and light interception in a temperate tree-based intercropping system of Eastern Canada. Agrofor Syst 88: 693-706. https://doi.org/10.1007/s10457-014-9721-6

Cannavo P, Harmand JM, Zeller B et al (2013) Low nitrogen use efficiency and high nitrate leaching in a highly fertilized Coffea arabica-Inga densiflora agroforestry system: A $15 \mathrm{~N}$ labeled fertilizer study. Nutr Cycl Agroecosystems 95:377394. https://doi.org/10.1007/s10705-013-9571-z

Cardinael R, Chevallier T, Barthès BG et al (2015a) Impact of alley cropping agroforestry on stocks, forms and spatial distribution of soil organic carbon - A case study in a Mediterranean context. Geoderma 259-260:288-299. https://doi.org/10.1016/j.geoderma.2015.06.015

Cardinael R, Mao Z, Prieto I et al (2015b) Competition with winter crops induces deeper rooting of walnut trees in a Mediterranean alley cropping agroforestry system. Plant Soil 391:219-235. https://doi.org/10.1007/s11104-0152422-8

Cardinael R, Chevallier T, Cambou A et al (2017) Increased soil organic carbon stocks under agroforestry: A survey of six different sites in France. Agric Ecosyst Environ 236:243255. https://doi.org/10.1016/j.agee.2016.12.011

Cardinael R, Guenet B, Chevallier T et al (2018a) High organic inputs explain shallow and deep SOC storage in a long-term agroforestry system - Combining experimental and modeling approaches. Biogeosciences 15:297-317. https://doi. org/10.5194/bg-2017-125

Cardinael R, Umulisa V, Toudert A et al (2018b) Revisiting IPCC Tier 1 coefficients for soil organic and biomass carbon storage in agroforestry systems. Environ Res Lett 13:1-20. https://doi.org/10.1088/1748-9326/aaeb5f

Cardinael R, Chevallier T, Guenet B et al (2019a) Organic carbon decomposition rates with depth and contribution of inorganic carbon to $\mathrm{CO} 2$ emissions under a Mediterranean agroforestry system. Eur Jounal Soil Sci. https://doi.org/10.1111 /ejss. 12908

Cardinael R, Hoeffner K, Chenu C et al (2019b) Spatial variation of earthworm communities and soil organic carbon in temperate agroforestry. Biol Fertil Soils 55:171-183. https://doi. org/10.1007/s00374-018-1332-3

Chander K, Goyal S, Nandal DP, Kapoor KK (1998) Soil organic matter, microbial biomass and enzyme activities in a tropical agroforestry system. Biol Fertil Soils 27:168-172. https://doi. org/10.1007/s003740050416

Charbonnier F, le Maire G, Dreyer E et al (2013) Competition for light in heterogeneous canopies: Application of MAESTRA to a coffee (Coffea arabica L.) agroforestry system. Agric For Meteorol 181:152-169. https://doi.org/10.1016/j. agrformet.2013.07.010

Chikowo R, Mapfumo P, Nyamugafata P, Giller KE (2004) Woody legume fallow productivity, biological N2-fixation and residual benefits to two successive maize crops in Zimbabwe. Plant Soil 262:303-315. https://doi.org/10.1023 /B:PLSO.0000037053.05902.60

Clivot H, Petitjean C, Marron N et al (2020) Early effects of temperate agroforestry practices on soil organic matter and microbial enzyme activity. Plant Soil. https://doi.org/10.1007 /s11104-019-04320-6

Corbeels M, Cardinael R, Naudin K et al (2019) The 4 per 1000 goal and soil carbon storage under agroforestry and conservation agriculture systems in sub-Saharan Africa. Soil Tillage Res 188:16-26. https://doi.org/10.1016/j.still.2018.02.015

den Herder M, Moreno G, Mosquera-Losada RM et al (2017) Current extent and stratification of agroforestry in the European Union. Agric Ecosyst Environ 241:121-132. https://doi.org/10.1016/j.agee.2017.03.005

Dupraz C, Wolz KJ, Lecomte I, Talbot G, Vincent G, Mulia R, Bussière F, Lafontaine HO, Andrianarisoa S, Jackson N, Lawson G, Dones N, Sinoquet H, Lusiana B, Harja D, Domenicano S, Reyes F, Gosme M, van Noordwijk M (2019) Hi-sAFe: A 3D agroforestry model for integrating dynamic tree-crop interactions. Sustainability 11:1-25. https://doi.org/10.3390/su11082293

Eichhorn MP, Paris P, Herzog F et al (2006) Silvoarable systems in Europe - Past, present and future prospects. Agrofor Syst 67:29-50. https://doi.org/10.1007/s10457-005-1111-7

Falkenmark M (2013) Growing water scarcity in agriculture: future challenge to global water security. Philos Trans R Soc A Math Phys Eng Sci 371:20120410. https://doi. org/10.1098/rsta.2012.0410

Feliciano D, Ledo A, Hillier J, Nayak DR (2018) Which agroforestry options give the greatest soil and above ground carbon benefits in different world regions? Agric Ecosyst Environ 254:117-129. https://doi.org/10.1016/j.agee.2017.11.032

Frouz J, Roubíčková A, Heděnec P, Tajovský K (2015) Do soil fauna really hasten litter decomposition? A meta-analysis of enclosure studies. Eur J Soil Biol 68:18-24. https://doi. org/10.1016/j.ejsobi.2015.03.002

Garnier E, Navas M-L (2012) A trait-based approach to comparative functional plant ecology: concepts, methods and applications for agroecology. A review. Agron Sustain Dev 32: 365-399. https://doi.org/10.1007/s13593-011-0036-y

Germon A, Cardinael R, Prieto I et al (2016) Unexpected phenology and lifespan of shallow and deep fine roots of walnut 
trees grown in a silvoarable Mediterranean agroforestry system. Plant Soil 401:409-426. https://doi.org/10.1007 /s11104-015-2753-5

Germon A, Robin A, Jourdan C (2020) Tamm Review: Deep fine roots in forest ecosystems: Why dig deeper ? For Ecol Manage 466:118135. https://doi.org/10.1016/j. foreco.2020.118135

Gnankambary Z, Bayala J, Malmer A et al (2008) Decomposition and nutrient release from mixed plant litters of contrasting quality in an agroforestry parkland in the south-Sudanese zone of West Africa. Nutr Cycl Agroecosystems 82:1-13. https://doi.org/10.1007/s10705-008-9165-3

Graves AR, Burgess PJ, Palma J et al (2010) Implementation and calibration of the parameter-sparse Yield-SAFE model to predict production and land equivalent ratio in mixed tree and crop systems under two contrasting production situations in Europe. Ecol Modell 221:1744-1756. https://doi. org/10.1016/j.ecolmodel.2010.03.008

Guillot E, Hinsinger P, Dufour L et al (2019) With or without trees: Resistance and resilience of soil microbial communities to drought and heat stress in a Mediterranean agroforestry system. Soil Biol Biochem 129:122-135. doi: S0038071718303869

Huo G, Zhao X, Gao X, Wang S (2020) Seasonal effects of intercropping on tree water use strategies in semiarid plantations: Evidence from natural and labelling stable isotopes. Plant Soil. https://doi.org/10.1007/s11104-020-04477-5

Ilstedt U, Bargués Tobella A, Bazié HR et al (2016) Intermediate tree cover can maximize groundwater recharge in the seasonally dry tropics. Sci Rep 6:1-12. https://doi.org/10.1038 /srep21930

Isaac ME, Borden KA (2020) Nutrient acquisition strategies in agroforestry systems. Plant Soil doi. https://doi.org/10.1007 /s11104-019-04232-5

Jackson RB, Canadell J, Ehleringer JR et al (1996) A global analysis of root distributions for terrestrial biomes. Oecologia 108:389-411. https://doi.org/10.1007 /BF00333714

Jose S, Gillespie AR, Seifert JR et al (2000a) Defining competition vectors in a temperate alley cropping system in the midwestern USA. 3. Competition for nitrogen and litter decomposition dynamics. Agrofor Syst 48:61-77. https://doi. org/10.1023/A:1006367303800

Jose S, Gillespie AR, Seifert JR, Biehle DJ (2000b) Defining competition vectors in a temperate alley cropping system in the midwestern USA. 2. Competition for water. Agrofor Syst 48:41-59. https://doi.org/10.1023/A:1006367303800

Keesstra SD, Bouma J, Wallinga J et al (2016) The significance of soils and soil science towards realization of the United Nations sustainable development goals. Soil 2:111-128. https://doi.org/10.5194/soil-2-111-2016

Kim DG, Kirschbaum MUF, Beedy TL (2016) Carbon sequestration and net emissions of CH4 and N2O under agroforestry: Synthesizing available data and suggestions for future studies. Agric Ecosyst Environ 226:65-78. https://doi. org/10.1016/j.agee.2016.04.011

Lavelle P, Decaëns T, Aubert M et al (2006) Soil invertebrates and ecosystem services. Eur J Soil Biol 42:3-15. https://doi. org/10.1016/j.ejsobi.2006.10.002
Lehmann J, Peter I, Steglich C et al (1998) Below-ground interactions in dryland agroforestry. For Ecol Manage 111:157169. https://doi.org/10.1016/S0378-1127(98)00322-3

Ling Q, Zhao X, Wu P et al (2020) Effect of the fodder species canola (Brassica napus L.) and daylily (Hemerocallis fulva L.) on soil physical properties and soil water content in a rainfed orchard on the semiarid Loess Plateau, China. Plant Soil. https://doi.org/10.1007/s11104-019-04318-0

Liu W, Zhu C, Wu J, Chen C (2016) Are rubber-based agroforestry systems effective in controlling rain splash erosion? Catena 147:16-24. https://doi.org/10.1016/j. catena.2016.06.034

Lorenz K, Lal R (2014) Soil organic carbon sequestration in agroforestry systems. A review. Agron Sustain Dev 34: 443-454. https://doi.org/10.1007/s13593-014-0212-y

Lubbers IM, Pulleman MM, Van Groenigen JW (2017) Can earthworms simultaneously enhance decomposition and stabilization of plant residue carbon? Soil Biol Biochem 105: 12-24. https://doi.org/10.1016/j.soilbio.2016.11.008

Luedeling E, Smethurst PJ, Baudron F, Bayala J, Huth NI, van Noordwijk M, Ong CK, Mulia R, Lusiana B, Muthuri C, Sinclair FL (2016) Field-scale modeling of tree-crop interactions: challenges and development needs. Agric Syst 142:5169. https://doi.org/10.1016/j.agsy.2015.11.005

Maeght J-L, Rewald B, Pierret A (2013) How to study deep roots - and why it matters. Front Plant Sci 4:1-14. https://doi.org/10.3389/fpls.2013.00299

Marsden C, Martin-Chave A, Cortet J et al (2020) How agroforestry systems influence soil fauna and their functions - a review. Plant Soil. https://doi.org/10.1007/s11104-01904322-4

Millennium Ecosystem Assessment (2005) Ecosystems and Human Well-being: Synthesis. Island Press, Washington, DC

Montagnini F, Jordan CF, Machado RM (1999) Nutrient cycling and nutrient use efficiency in agroforestry systems. In: Montagnini F, Ashton MS (eds) The Silvicultural Basis For Agroforestry Systems. CRC Press, Boca Raton, pp 131-160

Muchane MN, Sileshi GW, Jonsson M et al (2020) Agroforestry boosts soil health in the humid and sub-humid tropics: A meta-analysis. Agric Ecosyst Environ 295:106899. https://doi.org/10.1016/j.agee.2020.106899

Mulia R, Dupraz C (2006) Unusual fine root distributions of two deciduous tree species in southern France: What consequences for modelling of tree root dynamics? Plant Soil 281:71-85. https://doi.org/10.1007/s11104-005-3770-6

Nair PKR (1985) Classification of agroforestry systems. Agrofor Syst 3:97-128. https://doi.org/10.1007/BF00122638

Nair PKR, Buresh RJ, Mugendi DN, Latt CR (1999) Nutrient cycling in tropical agroforestry systems: myths and science. Agrofor Sustain Agric Syst 1-31. doi: https://doi. org/10.1201/9781420049473.ch1

Negash M, Starr M (2013) Litterfall production and associated carbon and nitrogen fluxes of seven woody species grown in indigenous agroforestry systems in the south-eastern Rift Valley escarpment of Ethiopia. Nutr Cycl Agroecosystems 97:29-41. https://doi.org/10.1007/s10705-013-9590-9

Nyamadzawo G, Nyamugafata P, Wuta M, Nyamangara J (2012) Maize yields under coppicing and non coppicing fallows in a fallow-maize rotation system in central Zimbabwe. Agrofor Syst 84:273-286. https://doi.org/10.1007/s10457-011-9453-9 
Oades JM (1984) Soil organic matter and structural stability: mechanisms and implications for management. Plant Soil 337:319-337

Ogle SM, Wakelin SJ, Buendia L et al (2019) Cropland - Chap. 5. In: Volume 4 - Agriculture, Forestry and Other Land Use. 2019 Refinement to the 2006 Guidelines for National Greenhouse Gas Inventories. IPCC, Hayama. https://www. ipcc-nggip.iges.or.jp/public/2019rf/index.html

Onim JFM, Mathuva M, Otieno K, Fitzhugh HA (1990) Soil fertility changes and response of maize and beans to green manures of leucaena, sesbania and pigeonpea. Agrofor Syst 12:197-215. https://doi.org/10.1007/BF00123474

Palm CA (1995) Contribution of agroforestry trees to nutrient requirements of intercropped plants. Agrofor Syst 30:105124. https://doi.org/10.1007/BF00708916

Pavlidis G, Tsihrintzis VA (2018) Environmental Benefits and Control of Pollution to Surface Water and Groundwater by Agroforestry Systems: a Review. Water Resour Manag. https://doi.org/10.1007/s11269-017-1805-4

Ponge JF, Pérès G, Guernion M et al (2013) The impact of agricultural practices on soil biota: A regional study. Soil Biol Biochem 67:271-284. https://doi.org/10.1016/j. soilbio.2013.08.026

Porporato A, Daly E, Rodriguez-iturbe I (2004) Soil Water Balance and Ecosystem Response to Climate Change. Am Nat 164:625-632. https://doi.org/10.1086/424970

Price GW, Gordon AM (1999) Spatial and temporal distribution of earthworms in a temperate intercropping system in southern Ontario, Canada. Agrofor Syst 44:141-149. doi: $10.1023 \% 2$ FA\%3A1006213603150

Rhoades CC (1997) Single-tree influences on soil properties in agroforestry: lessons from natural forest and savanna ecosystems. Agrofor Syst 35:71-94. https://doi.org/10.1007 /BF02345330

Rigal C, Xu J, Vaast P (2020) Young shade trees improve soil quality in intensively managed coffee systems recently converted to agroforestry in Yunnan Province, China. Plant Soil. https://doi.org/10.1007/s11104-019-04004-1

Rosenstock TS, Tully KL, Arias-Navarro C et al (2014) Agroforestry with N2-fixing trees: Sustainable development's friend or foe? Curr Opin Environ Sustain 6:15-21. https://doi.org/10.1016/j.cosust.2013.09.001

Rosenstock TS, Wilkes A, Jallo C et al (2019) Making trees count: measurement and reporting of agroforestry in UNFCCC national communications of non-Annex I countries. Agric Ecosyst Environ 284:106569. https://doi.org/10.1016/j. agee.2019.106569

Roupsard O, Audebert A, Ndour AP et al (2020) How far does the tree affect the crop in agroforestry? New spatial analysis methods in a Faidherbia parkland. Agric Ecosyst Environ 296:106928. https://doi.org/10.1016/j.agee.2020.106928

Rowe EC, Hairiah K, Giller KE et al (1998) Testing the safety-net role of hedgerow tree roots by $15 \mathrm{~N}$ placement at different soil depths. Agrofor Syst 43:81-93. https://doi.org/10.1023 /A: 1022123020738

Schroth G (1995) Tree Root Characteristics as Criteria for Species Selection and Systems-Design in Agroforestry. Agrofor Syst 30:125-143. https://doi.org/10.1007/978-94-017-0681-0_6

Schroth G (1998) A review of belowground interactions in agroforestry, focussing on mechanisms and management options.
Agrofor Syst 43:5-34. https://doi.org/10.1023 /a:1026443018920

Shi L, Feng W, Xu J, Kuzyakov Y (2018) Agroforestry systems: Meta-analysis of soil carbon stocks, sequestration processes, and future potentials. L Degrad Dev 29:3886-3897. https://doi.org/10.1002/ldr.3136

Sida TS, Baudron F, Ndoli A et al (2020) Should fertilizer recommendations be adapted to parkland agroforestry systems? Case studies from Ethiopia and Rwanda. Plant Soil. https://doi.org/10.1007/s11104-019-04271-y

Sierra J, Nygren P (2005) Role of root inputs from a dinitrogenfixing tree in soil carbon and nitrogen sequestration in a tropical agroforestry system. Aust J Soil Res 43:667-675. https://doi.org/10.1071/SR04167

Sileshi G, Mafongoya PL (2007) Quantity and quality of organic inputs from coppicing leguminous trees influence abundance of soil macrofauna in maize crops in eastern Zambia. Biol Fertil Soils 43:333-340. https://doi.org/10.1007/s00374006-0111-8

Six J, Elliott ET, Paustian K (2000) Soil macroaggregate turnover and microaggregate formation: A mechanism for $\mathrm{C}$ sequestration under no-tillage agriculture. Soil Biol Biochem 32:20992103. https://doi.org/10.1016/S0038-0717(00)00179-6

Six J, Bossuyt H, Degryze S, Denef K (2004) A history of research on the link between (micro)aggregates, soil biota, and soil organic matter dynamics. Soil Tillage Res 79:7-31. https://doi.org/10.1016/j.still.2004.03.008

Smith P (2004) How long before a change in soil organic carbon can be detected? Glob Chang Biol 10:1878-1883. https://doi. org/10.1111/j.1365-2486.2004.00854.x

Smith DM, Jackson NA, Roberts JM, Ong CK (1999) Root distributions in a Grevillea robusta-maize agroforestry system in semi-arid Kenya. Plant Soil 211:191-205. https://doi. org/10.1023/A:1004635414462

Somarriba E (1992) Revisiting the past: an essay on agroforestry definition. Agrofor Syst 19:233-240. https://doi.org/10.1007 /BF00118781

Szott LT, Fernandes ECM, Sanchez PA (1991) Soil-plant interactions in agroforestry systems. For Ecol Manage 45:127-152. https://doi.org/10.1016/0378-1127(91)90212-E

Terefe B, Kim D-G (2020) Shifting cultivation maintains but its conversion to mono-cropping decreases soil carbon and nitrogen stocks compared to natural forest in Western Ethiopia. Plant Soil. https://doi.org/10.1007/s11104-019-03942-0

Thorup-Kristensen K, Halberg N, Nicolaisen M et al (2020) Digging Deeper for Agricultural Resources, the Value of Deep Rooting. Trends Plant Sci 25:406-417. https://doi. org/10.1016/j.tplants.2019.12.007

Tilman D, Fargione J, Wolff B et al (2001) Forecasting Agriculturally Driven Environmental Change. Science 292: 281-284. https://doi.org/10.1126/science.1057544

Torquebiau EF (2000) A renewed perspective on agroforestry concepts and classification. Comptes Rendus l'Academie des Sci - Ser III 323:1009-1017. https://doi.org/10.1016 /S0764-4469(00)01239-7

Tully KL, Lawrence D (2012) Canopy and leaf composition drive patterns of nutrient release from pruning residues in a coffee agroforest. Ecol Appl 22:1330-1344. https://doi.org/10.1890 /10-2342.1

Tully KL, Lawrence D, Scanlon TM (2012) More trees less loss: Nitrogen leaching losses decrease with increasing biomass in 
coffee agroforests. Agric Ecosyst Environ 161:137-144. https://doi.org/10.1016/j.agee.2012.08.002

Udawatta RP, Kremer RJ, Adamson BW, Anderson SH (2008) Variations in soil aggregate stability and enzyme activities in a temperate agroforestry practice. Appl Soil Ecol 39:153160. https://doi.org/10.1016/j.apsoil.2007.12.002

van Noordwijk M, Lawson G, Soumaré A et al (1996) Root distribution of trees and crops: competition and/or complementarity. In: Ong CK, Huxley P (eds) Tree-crop interactions - a physiological approach. CAB International, pp 319-364

van Noordwijk M, Duguma LA, Dewi S et al (2018) SDG synergy between agriculture and forestry in the food, energy, water and income nexus: reinventing agroforestry? Curr Opin Environ Sustain 34:33-42. https://doi.org/10.1016/j. cosust.2018.09.003

van Noordwijk M, Barrios E, Shepherd K et al (2019) Soil science as part of agroforestry. In: Sustainable development through trees on farms: agroforestry in its fifth decade. Bogor, Indonesia: World Agroforestry (ICRAF) Southeast Asia Regional Program. pp 63-92

Vanlauwe B, Aihou K, Tossah BK et al (2005) Senna siamea trees recycle $\mathrm{Ca}$ from a Ca-rich subsoil and increase the topsoil $\mathrm{pH}$ in agroforestry systems in the West African derived savanna zone. Plant Soil 269:285-296. https://doi.org/10.1007 /s11104-004-0599-3

Villatoro-Sánchez M, Le Bissonnais Y, Moussa R, Rapidel B (2015) Temporal dynamics of runoff and soil loss on a plot scale under a coffee plantation on steep soil (Ultisol), Costa Rica. J Hydrol 523:409-426. https://doi.org/10.1016/j. jhydrol.2015.01.058

Vörösmarty C, Green P, Salisbury J, Lammers RB (2000) Global Water Resources: Vulnerability from Climate Change and Population Growth. Science 289:284-289. https://doi. org/10.1126/science.289.5477.284
Wartenberg AC, Blaser WJ, Rosshetko JM et al (2020) Soil fertility and Theobroma cacao growth and productivity under commonly intercropped shade-tree species in Sulawesi, Indonesia. Plant Soil. https://doi.org/10.1007/s11104-01803921-x

Young A (1989) Agroforestry for soil conservation. Wallingford, Oxon. U.K.: C.A.B. International, Nairobi : International Council for Research in Agroforestry

Zamora DS, Jose S, Napolitano K (2009) Competition for 15N labeled nitrogen in a loblolly pine-cotton alley cropping system in the southeastern United States. Agric Ecosyst Environ 131:40-50. https://doi.org/10.1016/j. agee.2008.08.012

Zhu X, Liu W, Chen J et al (2020) Reductions in water, soil and nutrient losses and pesticide pollution in agroforestry practices: a review of evidence and processes. Plant Soil. https://doi.org/10.1007/s11104-019-04377-3

Zingore SP, Mafongoya P, Nyamugafata P, Giller KE (2003) Nitrogen mineralization and maize yield following application of tree pruning to a sandy soil in Zimbabwe. Agrofor Syst 57:199-211. https://doi.org/10.1023/A:1024887225450

Zomer R, Trabucco A, Coe R et al (2014) Trees on farms: an update and reanalysis of agroforestry's global extent and socio-ecological characteristics. Working Paper 179. Bogor, Indonesia: World Agroforestry Centre (ICRAF) Southeast Asia Regional Program

Zomer RJ, Neufeldt H, Xu J et al (2016) Global Tree Cover and Biomass Carbon on Agricultural Land: The contribution of agroforestry to global and national carbon budgets. Sci Rep 6:1-12. https://doi.org/10.1038/srep29987

Publisher's note Springer Nature remains neutral with regard to jurisdictional claims in published maps and institutional affiliations. 